\title{
I arbetsmarknadens utkant - om långtidsarbetslösa ungdomars förhållningssätt till sin situation
}

\author{
ULLA RANTAKEISU
}

\begin{abstract}
I artikeln belyses hur långtidsarbetslösa ungdomar förhåller sig till sin arbetslöshetssituation och framtiden. Fyra idealtypiska mönster kan urskiljas. Dessa förhållningssätt avspeglar dels hur de värderar arbete samt dels vilken typ av resurser som mobiliseras. Differentieringen i olika förhållningssätt visar att situationen är särskilt problematisk för vissa medan den för andra inneburit betydligt mindre problem.
\end{abstract}

\begin{abstract}
Inledning
Ungdomars arbetslöshet anses särskilt problematisk för att vuxenblivandet även inom andra sfärer - skaffa sig bostad, bilda familj etc - försenas (Furnham, 1994). Denna artikel handlar om en grupp långtidsarbetslösa ungdomar i skogslän. Den tar fasta på en fråga som har belysts med en kvalitativ datametod: Hur förhåller de sig till sin arbetslöshetssituation och vad vill de uppnå i densamma?

Ungdomars etableringsmöjligheter påverkas i hög grad idag av förändrade villkor på arbetsmarknaden. En försämrad sysselsättningssituation, osäkrare anställningsformer (Gonäs, 1998), ökad otrygghet och
\end{abstract}

Ulla Rantakeisu är fil dr i socialt arbete och anställd vid institutionen för samhällsvetenskap, Karlstads universitet. höjd arbetsintensitet har kommit att karakterisera utvecklingen under 1990-talet (Social rapport, 2001). Dessa sammanhänger bland annat med ökade flexibilitetskrav till följd av 90-talets lågkonjunktur (Holmlund och Storrie, 2001).

Förutom förändrade villkor på arbetsmarknaden har kamrater, skola och andra samhällsinstitutioner fått större betydelse för att strukturera ungdomars liv i moderna samhällen (Malmberg, 1997). Exempelvis har utbildningskraven ökat, inom arbetslivet går utvecklingen mot allt högre grad av specialisering samtidigt som det för individen har blivit viktigare att känna att man är rätt person på rätt plats (Arnell Gustafsson, 1999). På en teoretisk nivå har dessa samhälleliga förändringar analyserats på en rad olika sätt och getts olika beteckningar såsom t.ex. högmodernitet, senmodernitet 
(Giddens, 1997, 2000) eller risksamhälle (Beck, 1998)

Enligt Beck (1998) kan nu bevittnas hur arbetsmarknadens förändringar försvagar kollektiva yrkes- och klasserfarenheter vilka kan kopplas samman med en individualiseringsprocess. Traditionella samhörighetsmönster tunnas ut vilket medför osäkerhet och en ökning av sociala och kulturella risker. På individnivå handlar det om att människor alltmer måste lita på de egna möjligheterna på en turbulent arbetsmarknad. Om förändringar tidigare skedde mer ritualiserat tenderar både utforskandet och konstruerandet av jaget idag ske som en del av en reflexiv process som förbinder jaget med social förändring (Giddens, 1997). En del hävdar att ett nytt samhällssystem håller på att växa fram och att klass- och könsförklaringar förlorar i betydelse. Andra är mer försiktiga. Furlong och Cartmel (1997) studerade vad det innebär för ungdomar att växa upp i risksamhället och hur möjligheterna att etablera sig i vuxenlivet påverkats. De drar slutsatsen att social bakgrund har störst förklaringsvärde för ungdomars framtid, likväl som möjligheter och hinder är förknippade med kön och etnicitet (Furlong och Cartmel, 1997). Oavsett om kontinuiteten $\mathrm{i}$ en moderniseringsprocess betonas eller om skeendet tolkas som en samhällsomvandling tycks samsyn dock råda om att situationen utmärks av en långtgående individualiseringsprocess (Jonsson, 1999).

Forskning om olika arbetslöshetskulturer, med vilket här avses att arbetslösheten har skiftande betydelse för de arbetslösa, har huvudsakligen identifierat tre dominerande kulturer (Therborn, 1995; se även Engbersen m.fl., 1993): Den konformis- tiska, den tillbakadragande samt den avvikande kulturen. Den förstnämnda innebär en anpassning till majoritetskulturen där arbetslöshet ses som ett negativt tillstånd. Tillbakadragandekulturen omfattar människor som gett upp hoppet och förhåller sig likgiltigt till arbete. Avvikandekulturen är målinriktad men de medel som används är alternativa och omfattar subkulturer där utanförskapet är politiskt, konstnärligt, kriminellt eller missbruksrelaterat. Dock saknas kunskap om vilka faktorer som leder till respektive arbetslöshetskultur (Therborn, 1995) och frågan är i vilken utsträckning dessa är giltiga i Sverige, i tider av hög respektive låg arbetslöshet etc.

Sverige gick in i ett nytt skede under 1990-talet då samhället gick från full sysselsättning till massarbetslöshet inom loppet av några år. Även om i stort sett alla samhällsgrupper drabbades av arbetslösheten drabbades vissa grupper mer än andra: Lågutbildade i större utsträckning än högutbildade, yngre oftare än äldre, män i större utsträckning än kvinnor (Lundborg, 2001). Ungdomar är en av de grupper som blev fattigare under nittiotalet (Social rapport, 2001) och kan betraktas som en av 90-tals-krisens stora förlorare. Uppväxtfamilj och offentlig sektor har fått ta ett större försörjningsansvar för att överbygga ungdomars etableringsproblem på arbetsmarknaden (Vogel, 1998; 1994). Trots att ungdomsarbetslösheten minskade under de sista åren före millennieskiftet var den fortfarande 1999 högre än någonsin under 1960-, 70- och 80-talen (Schröder, 2000).

Inom ungdomsgruppen finns dock viktiga skillnader. En bristande arbetsmarknadsförankring framstår som ett 
övergående problem för flertalet då rörligheten in och ut ur arbetslösheten är särskilt hög bland ungdomar (Furåker och Soidre, 1999). Men det finns ungdomar som mer permanent löper en risk att fastna $i$ en nedbrytande rundgång mellan arbetslöshet, olika former av arbetsmarknadsåtgärder, korta anställningar etc. (Blomskog och Schröder, 1999). Sannolikt är det denna grupp som riskerar att även få problem inom andra områden (Börjeson och Gullberg, 1999; Korpi och Stenberg, 2001).

Vår kunskap om vad långtidsarbetslöshet har inneburit för ungdomars livsvillkor i Sverige är fortfarande begränsad. Lindbladh och Bustos Castro (1999) studerade marginalisering bland arbetslösa ungdomar som var hänvisade till fattiga förorter $i$ en svensk storstad och berättelserna förmedlar en bild av desorientering i livssammanhangen som förstärktes av boendemiljöerna. Även om arbetslösa i vissa förortsmiljöer är särskilt utsatta berörs även andra områden när arbetsmarknaden hårdnar. Ungdomsarbetslösheten är betydligt högre i skogslänen i jämförelse framförallt med storstadsområden (Rantakeisu m.fl., 2000). Hur ser ungdomar i skogslän på sin situation efter en längre tid i arbetslöshet? Vad vill de uppnå? Vilken betydelse har den yttre livsmiljön?

I denna studie om långtidsarbetslösa ungdomar i ett skogslän har jag inspirerats av ett handlingsteoretiskt perspektiv (Hagström, 1999). Valet motiveras av att det centrala är interaktionen mellan yttre förhållanden och hur dessa förhållanden uppfattas av den enskilde individen. I samspelet mellan den unge arbetslöse och omgivande relationer samt strukturer formas deras förhållningssätt. Denna artikel definierar förhållningssätt som den referensram för handlandet som inbegriper värderingar och attityder vilka orienterar ungdomarna mot omvärlden. Ungdomarnas förhållningssätt till arbetslösheten kommer främst till uttryck i deras uppfattning i nu-situationen om vad som är viktigt att uträtta och uppnå. Det är i ungdomarnas egen beskrivning som analysen tar sin utgångspunkt.

Syftet med föreliggande studie är att undersöka hur långtidsarbetslösa ungdomar förhåller sig till sin arbetslöshetssituation och framtiden.

\section{Metod}

\section{Undersökningsdeltagare och urval}

Analysen i denna undersökning baseras på ett primärmaterial bestående av intervjuer med 50 långtidsarbetslösa ungdomar i åldern 2025 år och som ingår i en komparativ undersökning av ungdomsarbetslöshet och social exklusion i sex europeiska länder (Kieselbach m.fl., 2001). Materialet insamlades i Värmland hösten 1998/våren 1999. Tjänstemän vid lokala arbetsförmedlingar och Arbetsmarknadsintitut (AMI) frågade informellt långtidsarbetslösa ungdomar om eventuellt deltagande. Önskemålet var att få en bred representation av arbetslösa med i undersökningen. Arbetslösa ungdomar inskrivna vid AMI bedöms ha fler svårigheter på arbetsmarknaden $\mathrm{i}$ jämförelse med ungdomar inskrivna på arbetsförmedlingar vilket ökade möjligheterna att få ett bredare urval.

I föreliggande undersökning har en förnyad analys gjorts av 35 av de 50 inter- 
vjuerna. Följande krav ställdes vid sekundäranalysen; (a) att informationen i intervjuerna skulle vara tillräckligt rikhaltig för den frågeställning som ligger till grund för undersökningen. Möjligheterna att kontakta ungdomarna för en andra intervju saknades; (b) att det inte skulle föreligga några tveksamheter i tolkningen av arbetslöshetstidens längd. I primäranalysen jämställdes arbetsmarknadspolitiska åtgärder med arbetslöshet och långtidsarbetslöshet avsåg en arbetslöshetstid på ett år eller längre. Fleras situation innehöll, förutom av växlingen mellan arbetslöshet och arbetsmarknadsåtgärder, även tillfälliga arbeten. Om det i denna sekundäranalys rådde tveksamheter om huruvida den sammanlagda längden på tillfälliga jobb översteg tolv veckors heltidsarbete det senaste året uteslöts de ur analysen. Ovanstående två krav innebar att 15 intervjuer exkluderades från analysen.

Gruppen består av 16 kvinnor och 19 män. Merparten fördelar sig på två städer med ca 30000 respektive 80000 invånare. Vid intervjutillfället var 18 personer öppet arbetslösa och 17 i någon typ av arbetsmarknadsåtgärd. Sju personer hade 9-årig grundskola som högsta utbildning och resterande gymnasieexamen eller motsvarande som högsta utbildning. Av gruppen bodde 14 i föräldrahemmet, 11 hade eget boende och 10 personer bodde med andra släktingar, partners eller vänner.

\section{Datainsamlingoch frågeställningar}

Bakgrundsfrågor såsom ålder, utbildning, civilstånd $\mathrm{m} . \mathrm{m}$. besvarades vid intervjutillfället med hjälp av ett mindre formulär. Det huvudsakliga datamaterialet insamlades utgående från en intervjumanual bestående av öppna frågor och individuellt anpassade uppföljningsfrågor. Intervjumanualen bestod av sju tematiska områden: arbetsmarknadssituationen, ekonomisk situation, fritidsaktiviteter, relationer till anhöriga och vänner, erfarenheter av myndigheter, erfarenheter av rumslig miljö och psykosociala påfrestningar relaterade till arbetslöshet.

Då datainsamlingen ursprungligen gjordes med syftet att förstå vilka faktorer som kan leda till social exklusion bland långtidsarbetslösa ungdomar baserades intervjumanualen huvudsakligen på Kronauers (1998) sex dimensioner av social exklusion. Den datamängd som samlades in för detta syfte visade sig vid en förnyad läsning och analys kunna ställas mot nya aspekter.

Huvuddelen av frågorna var av tvärsnittskaraktär men såväl retrospektiva som prospektiva uppgifter ingår. Flertalet intervjuer varade mellan 1-2 timmar. De bandade intervjuerna skrevs ut ordagrant. Innan intervjuerna påbörjades fick intervjupersonerna besvara även en mindre enkät i vilken det fanns ett antal hälsorelaterade frågor. Frågeformuläret besvarades av 34 av de 35 intervjupersonerna som ingår i denna förnyade analys. Den innehöll bl.a. frågor om 'sömnproblem', 'maktlöshet' och 'oro'. Dessa var kopplade till en fyrgradig besvärsskala med följande svarsalternativ: $i$ stort sett dagligen, några gånger $i$ veckan, någon enstaka gång, samt har ej besvärats under de senaste tre månaderna. De som svarade att de besvärats $i$ stort sett dagligen eller några gånger i veckan redovisas. Variablerna hur ofta de "grubblar över hur det ska gå med ekonomin« och "oroar sig över 
att de inte har något arbete« var kopplade till en femgradig svarsskala där de som svarat $i$ stort sett dagligen eller några gånger i veckan redovisas.

\section{Bearbetning och analys}

Bearbetningen av intervjuerna var till stora delar induktiv även om den tog sin utgångspunkt i att söka klarlägga ungdomarnas förhållningssätt. Det första analyssteget, som vägleddes av huvudfrågan »hur förhåller sig individen till situationen och framtiden?", innebar att utifrån enskilda intervjuer urskilja olika förhållningssätt för att sedan jämföra intervjuerna med varandra. Efter- hand utkristalliserades fyra från varandra skilda typer. Idealtyper är förenklingar av empiriska fall (Giddens, 1994) och för idealtyper gäller, som Eneroth (1989) påpekar, att de inte till punkt och pricka behöver motsvara något empiriskt fall, dvs. ingen enskild intervjuperson behöver ha samtliga kvaliteter som ingår i typen men typen bör vara så trogen data att den skulle kunna finnas i verkligheten. I Starrin m.fl. (1991; sid 113) finns en användbar figur vars form jag har använt för att åskådliggöra hur olika återkommande teman i intervjuerna urskildes och sorterades av mig för att så småningom översättas till idealtypiska begrepp. Se figur 1 .

\section{Figur 1.}

Från intervjuernas vardagsspråk till idealtyper.

\begin{tabular}{|c|c|c|c|}
\hline $\begin{array}{l}\text { Förhållningssätt till: } \\
\text { Arbete }\end{array}$ & Myndigheter & Familj/vänner & Idealtyp: \\
\hline $\begin{array}{l}\text { Att få känna sig trygg } \\
\text { till att börja med } \\
\text { - att få en fast inkomst. }\end{array}$ & $\begin{array}{l}\text { De tjatar, 'börja plugga, } \\
\text { börja plugga'. D om } \\
\text { lyssnar inte på mig som } \\
\text { person men jag ger } \\
\text { mig inte. }\end{array}$ & $\begin{array}{l}\text { Vi har jättebra kontakt. } \\
\text { Pratar om allt. Hade jag } \\
\text { inte haft familjen skulle } \\
\text { man varit en sån som } \\
\text { inte vågar säga något. }\end{array}$ & Traditionalister \\
\hline $\begin{array}{l}\text { Tjäna pengar, helt klart. } \\
\text { jag drömmer ju om att } \\
\text { bli rik, det gör jag. }\end{array}$ & $\begin{array}{l}\text { Det vakande ö gat- 'jag } \\
\text { ser dig'. Det gick att } \\
\text { komma undan ganska } \\
\text { lätt om man ville. Blev } \\
\text { borttappad i datorn. }\end{array}$ & $\begin{array}{l}\text { D et har verkligen varit } \\
\text { ensamt. Jag har ingen } \\
\text { lust att snacka om det. }\end{array}$ & Vinddrivna \\
\hline $\begin{array}{l}\text { Jag skulle aldrig kunna } \\
\text { tänka mig att jobba på } \\
\text { ett jobb bara för att } \\
\text { tjäna pengar. }\end{array}$ & $\begin{array}{l}\text { Dom kan ju inte trolla } \\
\text { fram jobb men det } \\
\text { blir så sterilt. N u är det } \\
\text { utbildning som gäller } \\
\text { helt enkelt. }\end{array}$ & $\begin{array}{l}\text { Jätteviktigt med kom- } \\
\text { pisarna, sitta och prata } \\
\text { och diskutera.Vi har ju } \\
\text { planerat lite med hög- } \\
\text { skolan och allt det där. }\end{array}$ & Sökare \\
\hline $\begin{array}{l}\text { Jag har inte sökt ett } \\
\text { enda jobb för jag vet } \\
\text { vad jag vill göra. }\end{array}$ & $\begin{array}{l}\text { De ställer snarare } \\
\text { till förtret var tredje } \\
\text { månad. Jag har sagt jag } \\
\text { inte vill ha något jobb. } \\
\text { Det är ju synd om } \\
\text { dom. }\end{array}$ & $\begin{array}{l}\text { Det handlar bara om } \\
\text { hur man tar folk hela } \\
\text { tiden. Jag har aldrig } \\
\text { blivit kritiserad. }\end{array}$ & Frifräsare \\
\hline
\end{tabular}


Steg två i analysen bestod i att finna lämpliga sammanfattande begrepp för de olika idealtypernas förhållningssätt - vad skiljer mellan olika förhållningssätt. Arbetet bestod av ett alternerande mellan tolkning av data och ett successivt konstruerande av en typologimodell. Detta för att finna begrepp som inte bara 'passar' till data, utan avspeglar signifikanta aspekter eller syntetiserar empirin (Dahlgren, 1996). Ganska snabbt kunde jag knyta an till »arbetets värde» vilken har tillämpats $i$ samhällsvetenskaperna under flera decennier dock utan att det har blivit föremål för närmare begreppsanalys (Hallström, 1998). Däremot tog det betydligt längre tid att finna den andra huvudkategorin - "typ av resursmobilisering». De två huvudkategorierna - arbetets värde och typ av resursmobilisering - har båda dikotomiserats. Fördelen är att de blir överskådliga som analytiska redskap.

Bearbetning och analys har således skett i två steg som i praktiken inte strikt följer efter varandra utan snarare är det en rörelse fram och åter mellan data, typer och kategorier. Då datamaterialet ursprungligen insamlades för delvis ett annat syfte har analysen har varit hänvisad till det material som föreligger. Sekundäranalysen har emellertid den fördelen att ett omfattande datamaterial använts optimalt.

Resultatredovisningen avslutas med en analys av hälsodata som insamlades i enkätundersökningen. Detta för att belysa möjliga hälsomässiga implikationer av differentieringen av långtidsarbetslösa ungdomar.

\section{Resultat}

När ungdomarna förhåller sig till sin arbetslöshetssituation och framtidsplaner framträder två centrala dimensioner. Den första dimensionen är hur arbete värderas - om materiella ting, trygghet, arbetskamrater betonas eller självförverkligande och karriär betonas som utmärkande för ett bra arbete. Den andra dimensionen är typ av resursmobilisering, dvs. vad de har att tillgå för att åstadkomma vad de vill uppnå. Dessa kan i sin tur indelas i mer kollektiva eller mer individuella resurser. I det följande redovisas fyra idealtypiska förhållningssätt beroende på om de ger uttryck för en mer instrumentell eller en mer expressiv syn på arbete, dvs. om de betonar värdet av materiella ting såsom lön och trygghet eller självförverkligande, samt ifall de i huvudsak mobiliserar egna resurser eller resurser i sin nära omgivning .

De idealtypiska förhållningssätten till vad som är viktigt att uppnå i nuvarande situation kan således sammanfattas i en typologi där arbetsvärderingar och typ av resursmobilisering samspelar med varandra. Se figur 2.

1. Traditionalister ${ }^{l}$ har en traditionell syn på arbete - de vill ha försörjningen tryggad på den lokala arbetsmarknaden. Genomgående finns en negativ attityd till myndigheternas uppmaningar om vidareutbildning och geografisk rörlighet. Yrkesplanerna är modesta. Familjekollektivet mobi-

1 Traditionalisterna bestod av femton ungdomar varav nio var kvinnor. Medelåldern var 22 år. De flesta hade en yrkesinriktad gymnasieutbildning och föräldrarna hade huvudsakligen arbetaryrken. 


\section{Figur 2.}

Fyra idealtypiska förhållningssätt till vad som är viktigt att uppnå $i$ den livssituation de befinner sig i som funktioner av a) hur arbetet värderas och b) typ av resursmobilisering.

Arbetsvärderingar

Instrumentella

Expressiva

Typ av resursmobilisering

Kollektiva

Individuella

\begin{tabular}{|c|c|}
\hline 1.Traditionalister & 2.Vinddrivna \\
\hline 3.Sökare & 4.Frifräsare \\
\hline
\end{tabular}

liseras för att förhoppningen om arbete ska kunna upprätthållas. Betydelsen av släkten - av att känna sig hemma - blir en central tillgång då arbetslösheten begränsar möjligheterna att i ett arbete omsätta det egna praktiska kunnandet.

2. Vinddrivna ${ }^{2}$ har en önskan om lönearbete vilket som helst men hyser starka tvivel om de egna möjligheterna. Problemet accentueras av att uppväxtfamiljen är en relativt frånvarande resurs i tillvaron samtidigt som de är helt utelämnade till de offentliga instansernas granskande kontroll. En individualistisk hållning - att hålla problemen för sig själv - blir ett sätt att överleva. Tillvaron upptas av att inte tappa fotfästet i balansgången mellan innanför-

2 Vinddrivna bestod av sex ungdomar varav fyra var män. Medelåldern var 22 år. Tre hade yrkesinriktad gymnasieutbildning medan de andra saknade gymnasieutbildning eller hade avbrutit densamma. Föräldrarna hade huvudsakligen arbetaryrken.

3 Sökare bestod av tio ungdomar varav hälften var kvinnor. Medelåldern var 21 år. Hälften hade en teoretisk inriktning på gymnasieutbildningen. Ungefär hälften av föräldrarna var tjänstemän, övriga hade arbetaryrken förutom två som var småföretagare. skap och utanförskap. Ett ordinärt "Svensson-liv« ses närmast som ett svåruppnåeligt ideal.

3. Sökare ${ }^{3}$ befinner sig i en sökprocess tillsammans med kamrater som innefattar en hög flyttningsbenägenhet. Genomgående önskar man pröva på olika jobb för att finna ut vad man vill göra. I ett längre tidsperspektiv ingår ett meningsfullt arbete i livsplanen - helst intresseorienterat. Förutom familjen mobiliseras kamrater vilket överbrygger den egna osäkerheten inför arbetsmarknadens krav. Tillsammans med kamrater planeras för jobb, studier, utlandsvistelser m.m.

4. Frifräsare ${ }^{4}$ betraktar inte sig själva som arbetslösa, även om de i formell mening är det. Den aktuella arbetslösheten ingår i en långsiktig planering där yrkesvisioner är relativt exklusiva och knutna till egna intressen. De avser att uttrycka sig själva genom arbete. Överlag betonas den egna

4 Frifräsare bestod av fyra män och medelåldern var 23 år. Två hade en teoretisk gymnasieutbildning, den tredje hade studerat vid en folkhögskola och den fjärde hade avbrutit sina gymnasiestudier. Majoriteten av föräldrarna var yrkesarbetande tjänstemän. 
individualiteten - förmågan och resurserna att våga göra något annat än omgivningen. Vuxensamhällets arbetsvärderingar upplevs som förlegade. Självcentrerad instrumentalism präglar inställningen till offentliga insatser. Livets centrum kretsar kring det egna intresset.

Ovanstående typbeskrivningar är en abstraherad sammanfattning av ett empiriskt material. De flesta långtidsarbetslösa ungdomarna hamnade, som framgår av noterna, i traditionalisternas eller sökarnas förhållningssätt. Färre hade vinddrivnas respektive frifräsarnas förhållningssätt. Nedan konkretiseras typerna med hjälp av olika individer som svarar mot de olika idealtyperna.

\section{Traditionalister}

Arbetsvärderingarna är $i$ huvudsak instrumentella. För traditionalister är det viktigt att göra rätt för sig vilket innebär att de kan ta vilka arbeten som helst. Yrkesambitionerna är blygsamma och mestadels okvalificerade arbeten inom områden som handel, kontor, fastighetsskötsel etc. önskas. Traditionalister vill inte bli egen företagare och är skeptiska till 'svartjobb' då de inte vill ta de risker och den otrygghet som detta innebär. Att bli avlönad och att få något att göra är det viktigaste med arbete. Ester uttryckte vad som var viktigt med ett arbete:

[Att] få pengar så jag kan försörja mig själv ordentligt, att ha nagonting att göra så jag inte bara går hemma hela tiden.

Arbete önskas på lokala arbetsmarknaden. Vilket yrkesområde och under vilka villkor har ingen större betydelse. Förhoppningen är att korta påhugg, arbetsmarknadsåtgärder etc. ska leda till stabilare arbeten trots frustrationen att gång efter annan erfara att detta grusas. Med oro reflekterar de över hur den officiella diskursen och arbetsförmedlingen alltmer betonar kunskap och utbildning samtidigt som praktiskt arbete med händer värderas allt mindre. Detta beskrevs av Otto som ser teoretikerna ta plats vid hans tidigare arbetsplats, skogen:

Det var en som såga rätt igenom huggbyxorna, saggade av halva benet gjorde han. Det var en sån här teoretiker som trodde han kunde skogsarbete bara för att han hade godkänt på sågteknik. (...) Det är svairt att hitta jobb när man är praktiskt lagdidag.

Traditionalister är i regel negativa till vidareutbildning - „det är en väldig hysteri kring det där med att läsa vidare» (Tina) - inte minst för att de tidigare har haft ganska lite utbyte av skolan som institution.

Mobiliserar $i$ huvudsak kollektiva resurser knutna till lokalsamhället. Uppväxtfamilj och släkt framstår som ett sammanhållande kitt genom materiellt och omfattande emotionellt stöd under arbetslöshetssituationen. I brist på individuella resurser mobiliseras familjens och det är speciellt modern i familjen som på olika sätt uppmuntrar traditionalisterna. Detta illustreras av Emmas utsaga:

Vi sitter ofta och diskuterar och mamma försöker sätta sig in i det här med Arbetsförmedlingen. Det är ju dit [till föräldrarna] jag åker för att avreagera mig, när det krånglar med pengar från Försäkringskassan och allt det här. 
Det är när tilltron till myndigheter börjar vackla som behovet av att vända sig till familjen blir mest akut samtidigt som kontakter med arbetsförmedlingen är ett nödvändigt ont för att man ska få arbete, exempelvis måste handläggare träffas etc. Samtidigt har man inte riktigt förstått hur de offentliga institutionerna fungerar eller så tycker man att de egna erfarenheterna rimmar dåligt med arbetsförmedlingens officiella budskap. De har dessutom svårt att hävda de egna erfarenheternas giltighet; utbildning och geografisk rörlighet är måhända förnuftigt men inte för egen del.

Bland familj och släkt mobiliseras argument för den ihärdiga kampen för att få arbeta där man bor och känner sig trygg. Släktens entusiasm och stöd återgäldas på olika sätt. De generationsöverskridande relationerna förankrar dem till miljön genom att de är ömsesidiga. Ivan uttryckte sig såhär: »Ja, jag hjälper syrran att laga lite grejer och klipper gräsmattan åt henne och så, skruvar några muttrar i morfars bilu. Stödet innebär att traditionalister orkar upprätthålla en stark arbetsvilja och förhoppningar om arbete i framtiden.

Traditionalisternas utrymme för förändringar är ganska litet: »Jag är som jag är och det är ingen idé att tjata på en« (Otto). Det generationsöverskridande umgänget erbjuder identitet och trygghet när betydelsen av ett fast jobb inte har kunnat förverkligas. Så länge familjerelationerna finns lyckas de hålla den upplevda vanmakten - visavi en arbetsmarknad som inte har 'vanliga' jobb att erbjuda - på avstånd då man tydligt är bärare av ett förhållningssätt som inte längre uppskattas och efterfrågas. Förhoppningarna om att samhällets institutioner eller den lokala arbetsmarknaden kan tillhandahålla lösningar på arbetslösheten skjuts inte i sank tack vare mobiliseringen av familjen som kollektiv resurs. Där kan den egna värdigheten bibehållas eftersom man bryr sig om och är lika varandra.

\section{Vinddrivna}

Arbetsvärderingarna är i huvudsak instrumentella. Vinddrivna önskar förtjäna sitt levebröd i ett inrutat och varaktigt arbete: „Tjäna pengar helt klart. Det blir lite andra rutiner när man har nåt att göra, gå upp på morgonen och så» (Torbjörn). Vinddrivna uppehåller sig emellertid mycket vid dåtiden. Skolgången beskrivs som stökig. Torbjörn beskrev vad som hände sedan - när han hade gått ut gymnasiet:

Alla kompisar och saint som jag hade, de hade ju inte heller nåt att göra så vi umgicks på fritiden. Vi flöt ju runt och gjorde inte så mycket, ja, festa och var ute och härja på helgerna och sådär. (..) Vi var väl ute och var häftiga på stan och sånt där och bråka med folk. (Torbjörn) Samtidigt är arbete inte längre det primära här i livet även om man officiellt står till arbetsmarknadens förfogande. Vinddrivna söker inte jobb utan rör sig fram och åter mellan en position på arbetsmarknaden som arbetssökande och att stå utanför arbetsmarknaden. Det som rör arbete har blivit en formalitet utan några avsikter från vinddrivnas sida då de egna möjligheterna att få ett jobb betvivlas.

Antingen är yrkesplanerna inte formulerade eller så är framtidsdrömmarna ganska storstilade projekt. Att den stora drömmen förmodligen inte kan genomföras är mer 
uthärdligt än att misslyckas med att träda in i det som betraktas som ett ordinärt förvärvsarbetsliv. Bengt och Ninni beskrev sina drömmar enligt citaten nedan:

Jag vet faktiskt inte [vad jag vill göra $i$ framtiden]. Nej, jag har en dröm. Jag skulle vilja ha en liten pub på Jamaica. Det är bara en dröm jag har. Jag ska dit nån gång i alla fall. (Bengt)

Ja, [drömmen], det är ju att träffa en ordentlig karl. Det skulle jag vilja. Det skulle underlätta med tanke på [barnen]. Jag säger finge jag en karl som kunde försörja mig och jag visste att jag aldrig behövde ha ett jobb $i$ hela mitt liv, då skulle jag gärna gå hemma. (...) Ja, (skrattar), jag vet inte vart jag skulle träffa honom. I minutenkön eller postkön eller konsumkön. (Ninni)

Framtidsperspektivet är mycket kort - man tar varje dag som den kommer. Vinddrivna är på väg att etablera sig mer eller mindre utanför skötsamhetens gräns eller är medvetna om att de befinner sig vid en kritisk tidpunkt. Torbjörn beskrev det så här:

Jag känner att jag börjar bli gammal. 23 år, det är dags snart kanske. Det är väl dags att fixa till och få ett jobb. Men jag tror möjligheterna är ganska små.

Resurser som mobiliseras är $i$ huvudsak individuella. Banden till anhöriga är komplicerade då dessa verkar ha nog med sig själva eller bor alltför långt bort vilket innebär att det informella utbytet är bristfälligt. Det finns inslag i den egna tillvaron som vinddrivna beskriver att de undanhåller anhöriga. En individualistisk hållning där »man försöker själv« (Ninni) utmärker vinddrivna.

Vinddrivna har emellertid inte den typ av egna individuella resurser, t.ex. självförtroende och bra betyg, som krävs för att bli attraktiva på arbetsmarknaden. De beskriver att de på förhand vet att de skulle slås ut i konkurrens med andra sökande. Från deras horisont framstår de offentliga instanserna som helt främmande. Myndighetshandläggare ställer obegripliga krav från en hierarkisk position där vinddrivna upplever sig utelämnade åt kontroll och granskning. Bristen på reellt stöd från myndigheter och omgivning medverkar till att man bara har sig själv att lita till: „Det jag är rädd för är den dagen då jag inte orkar något mer och [det] verkligen står mig hit upp allting." (Ninni) Möten med myndighetshandläggare tar mycket energi i anspråk. Vinddrivna undviker dock direkt konfrontation utan så långt möjligt kommuniceras det som de uppfattar att handläggare vill höra - man måste exempelvis "försätta sig i en lägre stämning."(̊̊sa) Strategin mot det som uppfattas som yttre maktutövning blir att de låtsas vara arbetssökande samtidigt som man undviker att berätta något om de egentliga bekymren, "den biten som jag inte vill prata om, den vill jag inte prata om liksom» (Oscar), eller så uteblir man helt när myndigheterna kallar. Detta förhållningssätt - att klara sig själv, att behålla saker och ting för sig själv - antas för att inte helt förlora kontrollen över den egna tillvaron men innebär dock att rörelsen bort från arbetsmarknaden förstärks.

Vinddrivna håller sig till orten men en könsdifferentiering i det sociala rummet är tydlig. Det sociala sammanhanget är för kvinnornas del inskränkt och utmärks av isolering till hushållet och bostadsområdet där ensamheten blir tuff att bära: 
Det är skönt att vara ensam men det är, det blir att man känner sig som en utböling då, till och med $i$ [mataffären] så känner man sig som något jävla ufo när jag gick där ibland dom. (Åsa)

Avsaknaden av fullödiga band till uppväxtfamiljen gör att gruppen är relativt utelämnad till de relationer som finns till hands. För de vinddrivna männen kompliceras tillvaron av att den utspelar sig på 'gatan' och vid centrala platser i staden. Man har sökt sig till unga män med liknande intressen och utan arbete. Festandet och dagdrivarlivet är en viktig förenande punkt men uppfattningen om umgänget är kluvet. Valle beskrev sitt umgänge enligt följande:

Jag har ju umgåtts, dom kamrater jag har haft, det har varit allt ifrån bråkstakar till om man säger lite småfifflare då. Jag känner nästan varenda jävel som springer runt och fjantar sig $p a ̊$ stan.

\section{Sökare}

Arbetsvärderingarna är i huvudsak expressiva. Karakteristiskt för sökare är att arbete är nödvändigt för att få en inkomst men det bör i förlängningen också vara meningsfullt och intressant. De är öppna för att pröva på olika jobb och kan även flytta från orten för att få ett. Inom den närmsta framtiden kan man arbeta inom okvalificerade yrken:

Jag kan tänka mig ett sånt jobb liksom ett år, bara för att prova på och testa men jag vet att jag nog inte skulle stå ut en längre tid. (Olga)

Parallellt med ett kortsiktigt perspektiv har de även ett relativt långsiktigt perspektiv på tillvaron. Några vill inte längre arbeta med det som yrkesutbildningen i gymnasiet syftade till medan andra betraktar de första arbetserfarenheterna som skäl för att bida sin tid och finna lämpligare yrkes- eller livsinriktning. I det längre tidsperspektivet ingår studier om det är en förutsättning för förverkligandet av yrkesdrömmar. Samtidigt finns hinder på vägen; utbildningsplaner är diffusa eller så är man är osäker på om man klarar av högre studier. Artur beskrev det såhär:

Man måste ju testa lite innan man vet vad man vill göra, en del hoppar ju på högskolan direkt. Det är väl bra om dom vet vad dom vill bli men jag är inte helt säker. (...) Jag skyndar långsamt helt enkelt.

Sökarna är kräsna i sitt jobbsökande. Yrkesvisionerna är vaga även om en koppling mellan arbete och fritidsintressen görs - man önskar sig arbete orienterat mot intressen såsom musik, teater etc:

Jag skulle vilja prova att [arbeta], jag är väldigt intresserad av att ta bilder. Inte för att jag är speciellt duktig men jag tycker sånt är väldigt roligt. (Britta)

Sökare dras i regel till lite 'häftiga' arbetsmarknadsåtgärder, exempelvis att praktisera i en musikaffär där kamrater tittar in och man får en möjlighet att umgås med dem. Flera av dem arbetar också konkret med "egna företagsprojekt» som arbetsmarknadsåtgärd då välbefinnandet finns $i$ att tillsammans med sina kompisar få en möjlighet att vidareutveckla något man har ett intresse för. De är relativt optimistiska om framtiden. Det fixar sig då vuxenlivet inte riktigt står för dörren. "Man får ta det som det kommer liksom, så att det är rätt så lugnt."(Olle) 
Resor och vistelser utomlands ses som alternativ för nya livserfarenheter innan man slår sig till ro samtidigt som en dålig privatekonomi till följd av arbetslösheten lägger hinder i vägen:

Det jag drömmer om just nu är att hitta ett jobb så jag kan försörja mig själv, jobba ihop så mycket pengar jag bara kan, säga upp lägenheten och resa $i$ ett halvår. Sen komma tillbaka och kanske söka teaterskolor, eller ja, hitta nåt jag trivs med också. Jobba, leva livet och sen när jag ska binda mig ska jag flytta ut på landet. Ja, när jag blir stor. (Olga; min understrykning)

Resursmobiliseringen är i huvudsak kollektiv och framförallt kamraternas betydelse betonas. De har en öppenhet inför ungdomskulturer och trender. Mobiliseringen av vänner och kompisar ökar deras tilltro till möjligheterna att kunna ställa upp på de betingelser som arbetsmarknaden kräver. Tack vare kamrater söker man anamma eller förändra det egna förhållningssättet så att det går i linje med det som arbetsmarknaden efterfrågar, dvs. geografisk rörlighet, flexibilitet, studier etc. Förutsättningen är dock att man tillsammans med sina kompisar kan planera för den här inriktningen. Flera filar också på sina framtidsplaner tillsammans med jämnåriga, exempelvis att resa ihop, söka arbete eller börja studera vid högskola. Ett exempel på detta gavs av Britta:

Jag och några kompisar, vi har varit nere på platsbanken igår och kollade upp Oslo-jobb och skrev ut några [arbeten], så man ska väl skriva dit och så och sen ska vi väl åka dit.

De offentliga institutionerna kan vara behjälpliga då man kan få information om utbildningar, ekonomiskt stöd till jobbsökarresor etc. samtidigt som det är frustrerande att alltför få arbeten förmedlas. Emellertid är det uppväxtfamiljen men framförallt samvaron med kamrater som minskar glappet mellan det egna förhållningssättet och de krav som förmedlas som önskvärda av arbetsförmedling och arbetsmarknad.

\section{Frifräsare}

Arbetsvärderingarna är i huvudsak expressiva. Utmärkande för frifräsare är att de inte vill ha ett lönearbete vid tidpunkten för intervjun men i ett längre tidsperspektiv är målet utbildning och arbete. De accepterar inte traditionellt arbete av typen industriarbete då det betraktas som kvarlevor från en numera föråldrad arbetarkultur. Kalle, som ägnar sig åt musik, beskrev skillnaden mellan vuxensamhällets syn på arbete och det egna förhållningssättet enligt följande:

Dom är lite sådär som min farfar skulle kunna säga; 'Nu skaffar du ett jobb på en fabrik eller någonting.' (...) Vad är det som säger att jag inte träffar människor och sen när jag slutar spela känner en kille som jobbar på det skivbolaget $i$ Tyskland och där behöver dom en kille.

Yrkesplanerna är relativt exklusiva och knutna till det egna intresset, man satsar exempelvis på en karriär inom musik- eller filmbranschen och arbetslösheten ger dem möjlighet att utveckla egna förmågor. Frifräsare betonar att man inte vill arbeta med något man inte trivs med. Arbetet måste vara meningsfullt. De är mycket tydliga i 
sitt förhållningsätt till arbete - de avser att uttrycka sig själva genom arbete. Eller som Gösta framlägger det:

Jag vill inte göra nåt annat heller, för jag älskar musik. Det är det enda jag offrar väldigt mycket för. [...] Det finns människor som går runt hela sitt liv utan att känna vad fan de har på planeten att göra.

Skulle de exklusiva planerna inte förverkligas står andra dörrar öppna; data, media, konst, reklam, design etc. Den framtida karriären garderas genom att de även läser kataloger för högre utbildning för att finna alternativa yrkesvägar.

Frifräsare betraktar sig inte som arbetslösa utan arbetslösa är "dom andra" - de som inte klarar av att fylla dagarna med annat än passivt TV-tittande. Detta gav Kalle tydligt uttryck för:

På pappret ser det kanske ut som att jag har varit arbetslös i två år och inte gjort nåt utom suttit hemma och spela TV-spel men det är inte alls så. Jag är kanske arbetslös men inte sysselsättningslös eller sysslolös.

De anser att de själva har valt arbetslösheten och de är således själva ansvariga för att ta sig ur den utan inblandning från omgivningen eller från samhälleliga normer.

Mobiliserar $i$ huvudsak individuella resurser. Familj och vänner finns där för social samvaro men skapandet av sig själv via det egna intresset går före eventuella hänsyn till andra. Frifräsare har rest utomlands, arbetat inom olika branscher i landet eller upprätthåller ett omfattande kontaktnät tack vare sina intressen. Impulser från när och fjärran är centrala och kan befrämja den egna utvecklingen och kompetensen.
Kontaktnäten karakteriseras av normer där en ganska högt värderad frihet - att göra som man vill - accepteras. De uppvisar en hög flyttningsbenägenhet:

Jag är liksom inte rotad här. Jag vill inte rota mig så heller. Jag vill inte vara beroende över en geografisk plats liksom. (Martin)

De utnyttjar arbetsförmedlingen genom att formellt stå till arbetsmarknadens förfogande då det är ett villkor för den ekonomiska försörjningen. I övrigt ska myndigheter hålla sig borta och inte lägga sig i deras göranden och låtanden. Oberoende är att föredra och frifräsare undviker heller inte öppna konfliktsituationer med myndigheter för att markera oavhängigheten. Samtidigt har de inte blivit utsatta för någon större negativ kontroll eller av sanktioner från omgivningen. Detta återkom i samtalen med frifräsarna och Kalle uttryckte det så här:

Jag har inte sökt ett enda jobb i och med att jag hailler på med musiken som jag kan hålla på med i högst två år till. När jag varit på söka-jobb kurs på arbetsförmedlingen och vi ska skriva ansökningar och jag är den enda som har sagt att jag vill faktiskt inte ha ett jobb (skrattar). Dom förstår inte hur jag kan säga nåt sånt.

Överlag ges på olika sätt uttryck för den egna särarten utan att den upplevs som problematisk för dem själva. "Jag tänker inte som den gemene mannen i samhället» (Martin). De betonar den egna individualiteten och betraktar sig själva som rebeller eller privilegierade i förhållande till omgivningen. "Jag är så egen av mig. Jag är så lugn. Sköt dig själv och skit i andra." 
(Erland) Deras självvalda 'utanförskap' accepteras då andra förmodligen förutsätter att deras inställning till arbete kommer att förändras med tiden om de inte lyckas uppnå egna föresatser. De regler som frifräsare ställer upp för sig själva hjälper dem att kringgå de regler och normer som omgivningen har:

Jag är alltså en som dom kallar för free-rider liksom, jag cyklar dit jag vill liksom. Det är lättare att säga det på engelska för då fär man poängen bättre; 'lonely is not lonesome' (Martin).

\section{Klass- och könsmönster}

De fyra idealtypiska förhållningssätten sammanhänger med hur de arbetslösa ungdomarna värderar arbete och typ av resurser som mobiliseras. Men det finns även objektiva förhållanden som social bakgrund och utbildning som tenderar att villkora idealtypiska förhållningssätt och handlingsvägar. Traditionalister och vinddrivna kommer huvudsakligen från arbetarklassen och de flesta hade en yrkesorienterad gymnasieutbildning. Bland frifräsare, men även bland sökare, är en medelklassbakgrund och en teoretisk gymnasial utbildning vanligare.

Klassbakgrund tycks ha betydelse för vilka förhållningssätt som är möjliga. Det går således inte enbart att konstatera att vissa mobiliserar kollektiva resurser medan andra mobiliserar individuella utan även vilka värden eller normer som kommer till uttryck vid mobiliseringen har betydelse. För arbetarklassen är personliga, jämlika relationer en viktig premiss i den hjälp som erhålls vilket gör att myndigheternas interveneringar framstår som mer främmande än de gör i andra sociala skikt (Gullestad, 1983; Dahlgren m.fl., 1984). Att vinddrivna endast har sig själva att lita till gör att de är särskilt utsatta - de har inga alternativa kollektiva resurser till de som samhälleliga institutioner står för samtidigt som myndigheternas normer går stick i stäv med de egna. De normer som frifräsare framförallt ger uttryck för - konkurrens och framhävandet av egna förtjänster - passar väl en typ av handlande individer som arbetsmarknaden och samhälleliga institutioner förutsätter (Gullestad, 1983; Aspers, 2000). Tydligast framstår frifräsarnas förhållningssätt som det mest offensiva i relation till arbetsmarknaden.

I idealtyperna finns även en påtaglig könsdimension. Inslag av åtskilda könsmönster finns framförallt bland vinddrivna. Vinddrivna kvinnors socialt isolerade tillvaro innebär förmodligen att utsattheten, till skillnad mot de vinddrivna männen, inte är lika synlig. De sistnämndas tillvaro som i större utsträckning utspelas i offentliga miljöer, blir då troligen påtagligare för omgivningen. Det finns även en könsobalans i typologin: Det finns ingen kvinna bland frifräsare. Den sociala könsoch klasstrukturen tenderar att påverka kvinnors och mäns valmöjligheter. Sociala positioner innebär att möjligheterna att välja ett visst förhållningssätt är olika i skilda positioner (Jakobsen, 1999). Frågan är om unga kvinnor kan bryta mot dominerande livsmönster - exempelvis att öppet stå för att man inte söker arbete - och att det även accepteras av andra utan att de personliga kostnaderna blir för höga? 


\section{Idealtypiska förhållningssätt och ohälsa}

De intervjuade kan indelas i fyra idealtypiska förhållningssätt som benämndes traditionalister, vinddrivna, sökare och frifräsare. I tabell 1 nedan återfinns en sammanställning av hur många i respektive grupp som anger att de besvärats av olika former av ohälsa. Enkätmaterialet är emellertid litet och redovisningen bör därför endast ses som tentativ.

Bland vinddrivnaär det hälften eller mer än hälften som har uppgivit att de besväras av sömnproblem, maktlöshet, oro, grubblar över ekonomin eller oroar sig för att de inte har ett arbete att gå till. Bland traditionalister är det två femtedelar som har angett att de besväras av oro, grubblar över ekonomin eller oroar sig för att de inte har ett arbete att gå till. Bland sökarna är det en tredjedel som har uppgivit att de besväras av densamma. I tabellen kan ses att frifräsarnas svar avviker från de andra tre grupperna $\mathrm{i}$ en betydligt mer positiv riktning vad gäller olika besvärstyper. Ingen av frifräsarna har angett att de »i stort sett dagligen" eller "några gånger i veckan« besväras av sömnproblem, maktlöshet eller oro. De har heller inte uppgivit att de "i stort sett dagligen" eller "några gånger i veckan" oroar sig för att de inte har något arbete att gå till eller grubblar över ekonomin.

\section{Sammanfattning och diskussion}

Syftet med föreliggande studie var att undersöka hur långtidsarbetslösa ungdomar förhåller sig till sin arbetslöshetssituation och framtiden.

Studien visar att långtidsarbetslösa ungdomar inte kan klumpas ihop under en och samma etikett. Långtidsarbetslösa ungdomars förhållningssätt till vad de vill uppnå bör ses i ljuset av två centrala förhållanden; hur arbete värderas och vilken typ av resurser som mobiliseras. Fyra idealtyper i betydelsen gemensamma attityder, värderingar och handlingsorientering identifierades $i$ skenet av dessa två centrala förhållanden. De benämndes traditionalister, vinddrivna, sökare och frifräsare.

\section{Tabell 1.}

Sammanställning av hur många $i$ varje grupp som anger att de $i$ stort sett dagligen eller några gånger i veckan har haft olika typer av besvär.

\begin{tabular}{lccccc}
\hline & $\begin{array}{c}\text { Sömn- } \\
\text { problem }\end{array}$ & Maktlöshet & O ro & $\begin{array}{c}\text { O roar sig för } \\
\text { att inte ha } \\
\text { arbete att gă till }\end{array}$ & $\begin{array}{c}\text { Grubblar } \\
\text { over } \\
\text { ekonomin }\end{array}$ \\
\hline 1.Traditionalister $(n=15)$ & A ntal & Antal & A ntal & Antal & Antal \\
2.V inddrivna $(n=6)$ & 5 & 3 & 6 & 6 & 6 \\
3.Sökare $(n=9)^{1}$ & 3 & 3 & 4 & 4 & 4 \\
4.Frifräsare $(n=4)$ & 0 & 2 & 3 & 3 & 3 \\
${ }^{1}$ Att n-talet är 9 sammanhänger med att en person inte fyllde i enkäten. &
\end{tabular}


Ett ytterligare förhållande som studien sökte belysa var det eventuella sambandet mellan differentieringen av ungdomsgruppen i idealtypiska förhållningssätt och ohälsa. Det finns tendenser till mönster i undersökningen som bör lyftas fram. För det första uppvisar hälften eller mer än hälften av de vinddrivna besvär av olika slag såsom sömnproblem, maktlöshet etc. För det andra avviker frifräsarna från de andra tre grupperna i en mer positiv riktning vad gäller hälsan.

\section{Rörelser itvå-dimensionellt rum}

Idealtypiska förhållningssätt utgör teoretiska konstruktioner med vilka ungdomarnas förhållningssätt kan förstås. De är renodlingar och bör inte förväxlas med konkreta individer. Ungdomarna själva befinner sig i en ständig rörelse i ett gränsland mellan att vara ung och vuxen eller mellan integrering och exklusion. Deras problem är arbetslösheten även om de har skilda förhållningssätt till sin situation. Oavsett vad de i nuläget representerar är ingen fastlåst vid förhållningssättet - däremot kommer de att utifrån nu-situationen och de sociala förutsättningar som påverkar den att betona olika saker de vill uppnå.

Exempelvis kan ungdomar som ingår $\mathrm{i}$ idealtypen traditionalister börja tvivla på den egna förmågan att få arbete om familjens stöd tryter. Om arbetsmarknadens objektiva begränsningar förblir desamma riskerar vinddrivna att marginaliseras ytterligare. Inte minst visar vinddrivnas upplevda hälsobesvär att deras situation kan vara påfrestande. Sökarnas långsiktiga och mobila förhållningssätt kan förändras om man träffar en partner som ställer krav att bo kvar vid orten. Frifräsarnas möjligheter att ställa sig utanför givna sociala normer i samhället kan desarmeras om de egna arbetsidealen inte realiseras. Det mobila förhållningssättet kan då övergå i betydligt mindre rörligt vuxenliv.

\section{Diskussion}

Ungdomsarbetslösheten har rönt speciell samhällelig oro då den antagits kunna leda till ett förkastande av förvärvsarbete som norm och utvecklandet av avvikande livsformer (Carle, 1987; Grotenhuis och Meijers, 1994). Idealtyperna visar det nödvändiga i att göra några klarlägganden om ungdomarnas förhållningssätt.

I föreliggande studie skulle de fyra idealtyperna kunna lokaliseras inom ramen för de tre dominerande arbetslöshetskulturer som identifierats i andra studier enligt Therborn (1995). Traditionalister och sökare skulle kunna hänföras till en konformistisk kultur medan (de manliga) vinddrivna och frifräsarna skulle kunna hänföras till avvikandekulturen. De kvinnliga vinddrivna kan tänkas återfinnas i tillbakadragandekulturen. Dock kan konstateras att en del av de skillnader $\mathrm{i}$ förhållningssätt som finns i föreliggande studie inte framkommer om indelningen utgår från dessa tre arbetslöshetskulturer. Exempelvis sammanfaller inte vinddrivnas och frifräsarnas förhållningssätt helt med avvikandekulturen. Påpekas bör att dessa arbetslöshetskulturer formas av endera inordningen, uppgivandet eller avvikelsen från arbetsnormen vid arbetslöshet emedan 
denna studies idealtyper formeras runt förhållningssätt som, vill jag hävda, kan existera oavsett om ungdomarna är arbetslösa eller inte.

Även om samtliga i denna studie har en ambition att skaffa sig ett förvärvsarbete signalerar framförallt de vinddrivna att det finns en minoritet unga långtidsarbetslösa som permanent riskerar att marginaliseras på den svenska arbetsmarknaden. Detta stämmer ganska väl överens med nyligen publicerade studier (Virtanen, 1996; Hammer, 2000). I en finsk studie identifierades fyra olika typer av långtidsarbetslösa ungdomar baserat på en analys av registerinformation; (1) omständigheternas offer; (2) arbetsavvisarna; (3) dagdrömmarna, och (4) reflexivitetsförlorarna (Virtanen, 1996). De sistnämnda hade drag gemensamma med gruppen vinddrivna då de utgjorde en liten grupp av arbetsmarknadsexkluderade ungdomar som är både svåra att nå och hjälpa. Vinddrivna har periodvis varit avskrivna som arbetssökande även om tillståndet inte är oåterkalleligt. Traditionalister ser sig som vuxna och idealet är förvärvsarbete där arbetslösheten innebär att man inte kan etablera sig även i andra avseenden. Sökare befinner sig i en mening i en övergångsfas som kan sägas karakteriseras som en förlängd ungdomstid. Frifräsare har i ett längre perspektiv siktet inställt på förvärvsarbete. De tendenser som finns i föreliggande studie visar det fruktbara i att differentiera unga långtidsarbetslösas förhållningssätt till sin situation. Inte minst har det betydelse för en diskussion om lämpliga samhällsinsatser för att långtidsarbetslösa ungdomar ska kunna realisera den egna försörjningen. Insatser lämpliga för vinddrivna är förmodligen inte alls lämpliga för frifräsare. Vinddrivna förefaller särskilt utsatta då de är extremt beroende av myndigheternas insatser samtidigt som de kämpar för att dra sig ur detta ensidiga beroendeförhållande.

Harding och Sewel (1992) har betonat vikten av att beakta sociala miljöer när forskning om arbetslöshet tolkas då den övervägande delen av forskningen inte har kontextualiserat arbetslösheten. Det finns anledning att anknyta till Hagströms (1990) studie bland företrädesvis yrkesarbetande medelklass- och storstadsungdomars förhållningssätt till arbete där ett genomgående mönster var de förhållandevis höga kraven på arbeten. I denna studie dominerar snarare det omvända - lågt ställda krav på arbeten där majoritetsgruppen - traditionalisterna - inte tycks ge ungdomsperioden samma subjektiva betydelse som ungdomarna i Hagströms studie. Skillnaderna kan dels bero på klass- och könsmönster etc. men även den närmiljö som mindre samhällen erbjuder.

Samtidigt bör det betonas att det inte är så att de arbetslösa ungdomarna passivt accepterar yttre handlingsvillkor utan att reflektera över dem utifrån den konkreta situationen, exempelvis utifrån arbetsmarknadens många krav. Även om ett stort ansvar läggs på den enskilde individen att utifrån valmöjligheter och egna värderingar slå sig fram på arbetsmarknaden visar studien att det finns tydliga skillnader i förhållningssätt.

Resultat som visar skilda hälsoeffekter av arbetslöshet har påvisats även i andra studier (se t.ex. Nordenmark, 1995; Hagquist och Starrin, 1996; Hammarström, 
1996) och det är viktigt att påpeka att det empiriska materialet i föreliggande arbete är mycket litet. Ohälsa bland unga arbetslösa har rönt betydligt mindre samhällelig uppmärksamhet än eventuella avvikelser från arbetsnormen (Fryer, 1997). De mönster som här framträder kan tolkas som indikatorer på att hälsa differentieras med avseende på de fyra idealtyperna. I en större undersökning skulle dessa frågor närmare och säkrare kunna belysas. En annan fråga att mer detaljerat studera är förhållningssättens koppling till klass, kön, etnicitet och samhällsförändring.

Folkhälsoinstitutet har finansierat forskningen. Jag vill tacka Erik Forsberg för många värdefulla synpunkter på tidigare artikelutkast.

\section{Referenser}

Arnell Gustafsson, U (1999) „Från utbildning till arbete« i Hagström, T., red: Ungdomar i övergångsåldern. Lund: Studentlitteratur.

Aspers, P (2000) "Socialt kapital, dygder och hälsa» i Sociala skyddsnät och socialt kapital. Forskningsrådsnämnden Rapport nr 11, Stockholm.

Beck, U(1998) Risksamhället. Påväg mot en annan modernitet. Göteborg: Daidalos.

Blomskog, S, Schröder, L (1999) „Vilka ungdomar blir arbetslösa?" i Börjeson, M., Gullberg A., red: I vuxenlivets väntrum. Umeå: Boréa Bokförlag.

Börjeson, M, Gullberg, A (1999) "Inledning" i Börjeson, M., Gullberg, A., red: I vuxenlivets väntrum. Umeå: Boréa förlag.

Carle, J (1987) "Youth unemployment - individual and societal consequences, and new research approaches" Social Science \& Medicine, 25, 147-152.

Dahlgren, L (1996) „Fältforskning - En distanslös eller distanserande verksamhet?" i Svensson, P-G., Starrin, B., red: Kvalitativa studier i teori och praktik. Lund: Studentlitteratur.

Dahlgren, L, Lindgren G, Lundström I (1984) Familjekollektivet. Sociologiska institutionen Forskningsrapport nr 80, Umeå universitet.

Eneroth, B (1989) Hur mäter man wvackert»? Stockholm: Natur och kultur.
Engbersen, G, Schuyt, K, Timmer, J, Van Waarden, F (1993) Cultures of Unemployment. A comparative look at long-term unemployment and urban poverty. Boulder: Westview Press.

Fryer, D (1997) "International perspectives on youth unemployment and mental health: some central issues" Journal of Adolescence, 20, 333342.

Furlong, A, Cartmel, F (1997) Young people and social change. Individualization and risk in late modernity. Buckingham: Open University Press.

Furnham, A (1994) "The psychosocial consequences of youth unemployment" i Petersen A C., Mortimer J T., red: Youth unemployment and society. Cambridge: University Press.

Furåker, B, Soidre, T (1999) "Marginaliseringsmönster på arbetsmarknaden" i Gullberg A., Börjeson, M., red: I vuxenlivets väntrum. Umeå: Boréa Bokförlag.

Giddens, A (1994) Sociologi, vol 2. Lund: Studentlitteratur.

Giddens, A (1997) Modernitet och självidentitet. Göteborg: Daidalos.

Giddens, A (2000) Modernitetens följder. Lund: Studentlitteratur.

Gonäs, L (1998) »Om den svenska välfärdsstatens omvandling och det könsuppdelade arbetet« i 
Starrin, B., Svensson, R., red: Sverige efter välfärdskrisen. Umeå: Boréa Bokförlag.

Grotenhuis te H, Meijers, F (1994) „Societal consequences of youth unemployment" i Peterssen A C., Jeylan T., red: Youth unemployment and society. New York: Cambridge University Press.

Gullestad, M (1983) „Omsorg og subkultur» Tidskrift for samfunnsforskning, 24, 203-220.

Hagström, Tom (1990) Ungdomars livsstilar och förhållningssätt till arbete. Arbete och hälsa, 1990:4, Arbetsmiljöintsitutet, Stockholm.

Hagström, T (1999) »Ungdomars förhållningssätt till arbete« i Hagström, T., red: Ungdomar $i$ övergångsåldern. Lund: Studentlitteratur.

Hagquist, C, Starrin, B (1996) "Youth unemployment and mental health - gender differences and economic stress" Scandinavian Journal of Social Welfare, 5, 215-228.

Hallström, N-E (1998) Arbete eller bidrag. Centrum för kommunstrategiska studier, rapport nr 1998:2, Linköping: Linköpins universitet.

Hammarström, A (1996) Arbetslöshet och ohälsa - om ungdomars livsvillkor. Lund: Studentlitteratur.

Hammer, T (2000) "Mental health and social exclusion among unemployed youth in Scandinavia. A comparative study" International Journal of Social Welfare, 9, 53-63.

Harding, L, Sewel, J (1992) „Psychological health and employment status in an island community" Journal of Occupational and Organizational Psychology, 65, 269-275.

Holmlund, B, Storrie D (2001) »Temporary Work in Turbulent Times: The Swedish Experience» Manuskript, utkast 1 mars.

Jakobsen, L (1999) Livsform, kön och risk. Lund: Arkiv Förlag.

Jonsson, B (1999) „Unga vuxna, deras livsprojekt och tankar om framtida yrke« i Hagström, T., red: Ungdomar i övergångsåldern. Lund: Studentlitteratur.

Kieselbach,T, van Heeringen, K, La Rosa, M, Lemkow, L, Sokou, K, Starrin, B (2001) Living on the Edge. Opladen: Leske Budrich.

Korpi, T, Stenberg S A (2001) "Massarbetslöshetens Sverige - arbetslöshetens karaktär och effekter på individers levnadsförhållanden«i Välfärd och arbete $i$ arbetslöshetens årtionde, Socialdepartementet, SOU 2001:53.

Kronauer, M (1998) "Social exclusion' and the 'underclass' - new concepts for the analysis of poverty" i Andress H J., red: Empirical Poverty Research in a Comparative Perspective. Aldersho: Ashgate.

Lindbladh, E, Bustos Castro P (1999) "Ung och arbetslös. Om marginalisering, identitet och risk" i Härenstam, A., Lundberg, U., Lindbladh, E., Starrin, B., red: I vanmaktens spår. Umeå: Boréa Bokförlag.

Lundborg, P (2001) „Konjunktur- och strukturproblem i 90-talets arbetslöshet" Ekonomisk debatt, 29 (1) 7-18.

Malmberg, I (1997) „Ung, modern och arbetslös» Nordisk Sosialt Arbeid, 79-87.

Nordenmark, M (1995) "Kvinnlig" och "manlig" arbetslöshet" Arbetsmarknad \& Arbetsliv, 1, 31-44.

Rantakeisu, U, Forsberg, E, Kalander-Blomqvist, M, Starrin, B (2000) "Youth unemployment and social exclusion in Sweden" i Kieselbach, $\mathrm{T}$ (red.) Youth unemployment and social exclusion. Opladen: Leske Budrich.

Schröder, L (2000) Ungdomsarbetslösheten $i$ ett internationellt perspektiv. Stockholm: Institutet för social forskning.

Social Rapport (2001) Socialstyrelsen, Stockholm.

Starrin, B, Larsson, G, Dahlgren, L, Styrborn, S (1991) Från upptäckt till presentation. Lund: Studentlitteratur.

Therborn, G (1995) „Patterns and meaning of unemployment" Scandinavian Journal of Social Welfare, 4, 122-130.

Virtanen, P (1996) The making of a new underclass among the unemployed youth. Labour Policy Studies, Helsinki: Ministry of Labour.

Vogel, J (1994) Ungdomars välfärd och förändringar. Rapport till Barn- och ungdomsdelegationen och Generationsutredningen, SOU 1994:73.

Vogel, J (1998) „Välfärdssverige på 90-talet. Särart och framtid« i Starrin, B., Svensson, R., red: Sverige efter välfärdskrisen. Umeå: Boréa Bokförlag. 


\section{Summary}

\section{Living on the edge of the labour market. How long-term unemployed youth relate to their situation}

The article discusses what long-term unemployment means for young people. This qualitative study, on long-term unemployed youth in a "forest county", shows that the way they relate to what they want to achieve can be differentiated in relation to two central circumstances: the value they attach to work and the kind of resources they mobilise. Four ideal types, characterised by common values and paths of action, were constructed in the light of these two conditions: the "traditionalists", the "drifters", the "seekers" and the "free spirits".

A characteristic feature of the "traditionalists" was an instrumental attitude to work - they aimed at having work in the local employment market without any demands for a career. They mobilised collective resources - primarily the family they grew up in - to reduce their vulnerability vis-à-vis the employment market.

The "drifters" had an instrumental attitude to work, while at the same time they were resigned to not finding a job, an attitude that was reinforced by the fact that they were forced to depend on their own individual - carefully trained, but scanty - resources.

The "seekers» valued work as means of expression, and were still engaged in the process of seeking work and a way of life in which collective resources - particularly friends - were mobilised in order to reduce the gap between their desires and the employment market.

The "free spirits'" evaluation of work was expressive - they did not seek work actively and were opposed to traditional employment since their main interest would ultimately become their means of gainful employment. Using their own resources to create themselves went before whatever respect they might have for the opinions or norms of other people.

Another relationship that came to light was a possible link between the group differentiation and mental ill health. A pattern seems to appear which can be interpreted as possible indications that the four groups have different mental health status. 